\title{
Typology of the Phytoplankton Community of Dohou Lake, Drinking Water Supply Source in Duékoué Town (Western Côte d'Ivoire)
}

\author{
ATTOUNGBRE Kouakou Séverin \\ Jean Lorougnon Guédé University, Côte d'Ivoire \\ NIAMIEN-EBROTTIE Julie Estelle \\ Nangui Abrogoua University, Côte d'Ivoire \\ KOUAMÉ Kouamé Martin \\ Jean Lorougnon Guédé University, Côte d'Ivoire \\ BOUSSOU Koffi Charles \\ Jean Lorougnon Guédé University, Côte d'Ivoire \\ ALIKO N'Guéssan Gustave \\ Jean Lorougnon Guédé University, Côte d'Ivoire \\ KONAN Koffi Félix \\ Jean Lorougnon Guédé University, Côte d'Ivoire
}

Received: December 6, 2019

doi:10.5296/jee.v11i1.16337
Accepted: January 24, 2020 Published: January 26, 2020

URL: https://doi.org/10.5296/jee.v11i1.16337

\begin{abstract}
The objective is to study the phytoplankton community of Dohou Lake in order to contribute to the knowledge of its ecological quality. For this purpose, monthly samplings were carried out annually between October 2017 and September 2018. The studied physicochemical parameters (Temperature, Electrical conductivity, $\mathrm{pH}$, Dissolved oxygen, Transparency, Depth, Total nitrogen, Nitrate, Nitrite, Total phosphorus) varied significantly over time. During the
\end{abstract}


rainy season months, Dohou Lake is influenced by high values of total phosphorus, total nitrogen, conductivity, nitrate, $\mathrm{pH}$, transparency and depth. However, in the dry season, the lake is characterized by high values of temperature, nitrite, dissolved oxygen and conductivity. For the phytoplankton community, 373 phytoplankton taxa divided into 111 genera, 51 families, 24 orders, 11 classes and 7 phyla (Chlorophyta, Euglenophyta, Cyanobacteria, Bacillariophyta, Pyrrophyta, Chrysophyta and Xanthophyta) have been identified. Chlorophyta with $50.67 \%$ is the most represented in the taxonomic richness of the environment. Total phytoplankton densities oscillate between $10010^{5}$ cells / L (August) and $32110^{5}$ cells / L (February) with high proportions of Cyanobacteria greater than $45 \%$ during each month of the rainy season. The highest values of Shannon and Equitability diversities are observed during the dry season months.

Keywords: Phytoplankton community, Dohou Lake, Diversity, Physicochemical parameters

\section{Introduction}

For the satisfaction of vital needs, man has been led to master and dominate his environment. One of the voices of this quest for well-being has manifested itself in the control of Water. Storage of large amounts of water during rainy seasons to address dry season water shortages will lead to the creation of artificial water reservoirs (Baxter \& Glaude, 1980).

In Côte d'Ivoire, to meet drinking water needs, surface water is exploited and processed to supply urban and rural populations (Eblin et al., 2014). This is the case of Dohou Lake in Duékoué used by the Water Distribution Company of Côte d'Ivoire (SO.DE.CI) to supply the population of the city with drinking water. This lake, formerly the extension of the city, is today subject to several human activities because of its position near the city.

Rapid and unplanned urbanization, market gardening, artisanal gravel quarries and mechanical garages on the edge of the lake make it a reservoir of urban effluent. Is the latter likely to impact the quality of this water? In order to be better located and to minimize the health risks, the examination of the quality of this water body is therefore necessary and imperative. This exercise involves studying both the chemical quality of water and biological diversity. A recent study was conducted by Kouame et al. (2019) to characterize the typology of this water from physico-chemistry and bacteriology. However, the measurement of physico-chemical parameters makes it possible to collect only simple and punctual information and their concentrations seem to influence aquatic fertility (Naselli-Flores, 2000).

To further contribute to the knowledge of the ecology of Lake Dohou, it was therefore necessary to consider the structure of the community of certain aquatic organisms, which gives a clear idea of the quality of the water, confirming the physicochemical values obtained from the same surveys, which allows us to assess the state of health of the given ecosystem (Morin, 2006). In this context, phytoplankton is therefore one of the most dynamic indicators (Collins et al., 2014, Nunes et al., 2018) because of its high species diversity and high growth rates (up to more than one division). per hour (Furnas, 1991) and its rapid responses to changes in environmental conditions (Anneville et al., 2008). These organisms are at the base of the food web and are the first link in this network to respond to even the most discrete environmental disturbances (Hays et al., 2005). The responses are variable and can be manifested in terms of the degree of disturbance in time and space. However, too much 


\section{Macrothink}

phytoplankton production can affect the quality of drinking water and cause various ecological and health problems (Rondel et al., 2008). These blooms are particularly responsible for significant deoxygenation of the water column that can lead to high mortality among other pelagic communities. The trophic impasse that certain species represent, because of their toxicity, their size or their poor nutritional quality, can also lead to a significant reduction in the abundance and diversity of their predators and, consequently, higher trophic levels. (Carmichael et al., 2010).

The objective is to study the phytoplankton community of Dohou Lake in order to contribute to the knowledge of its ecological quality.

\section{Material and Methods}

\subsection{Study Area}

Dohou Lake is in the town of Duékoué, a town located in the west of Côte d'Ivoire at $470 \mathrm{~km}$ from Abidjan. This Dohou lake belongs to the Sassandra river basin in the Guémon region. This locality enjoys a humid tropical climate, characterized by a rainy season (April to October) and a dry season (November to March) (Brou, 2005). The vegetation consists of dense moist forest marked by grassland areas (Brou, 2005) and soils are generally ferralitic and hydromorphic (Kouassi et al., 2012). On the outskirts of the city of Duékoué on the road to Man, Lake Dohou is an artificial reservoir of water to supply the population of this city with drinking water. It covers an area of about $1 \mathrm{~km}^{2}$ (Figure1) between latitudes $6^{\circ} 45^{\prime} 07 " 73$ and $6^{\circ} 45^{\prime} 35^{\prime \prime} 91 \mathrm{~N}$ and longitudes $7^{\circ} 21^{\prime} 06.25$ and $7^{\circ} 21^{\prime} 49.31 \mathrm{~W}$. The lake is subject to several human activities including fishing, vegetable crops, artisanal gravel quarries, mechanical garages and farms nearby. It also receives waste runoff from runoff as well as wastewater from nearby homes and the city.

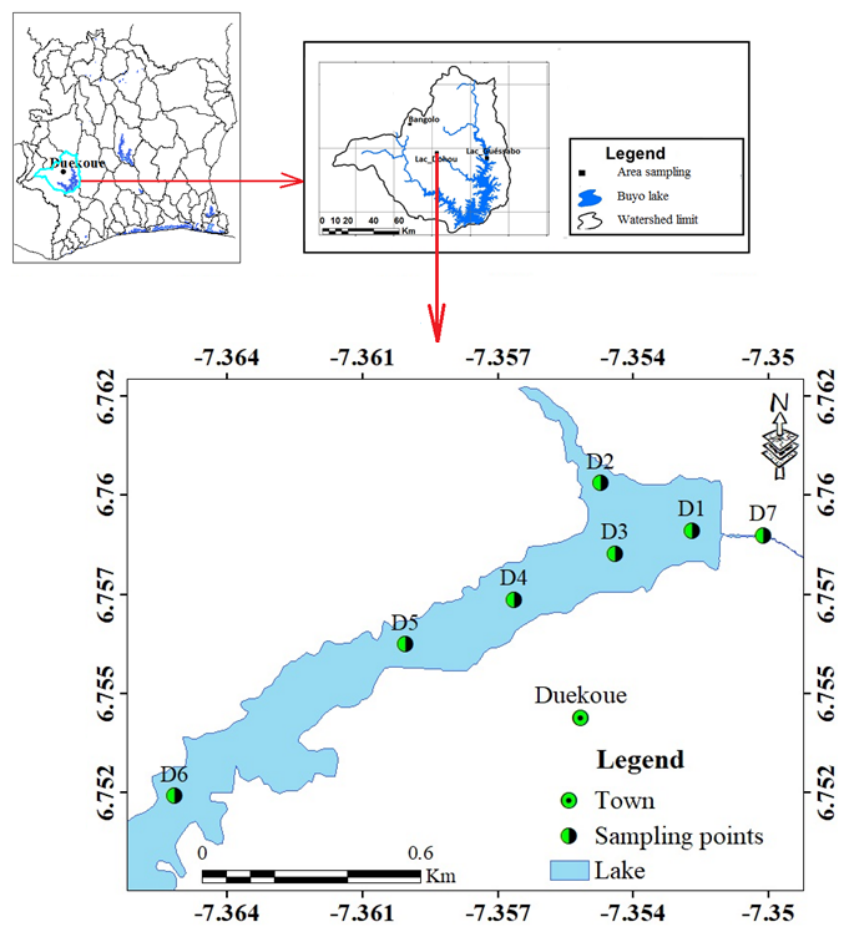

Figure 1. Map showing position of sampling points on Dohou Lake

\subsection{Sampling}


Sampling was conducted annually between October 2017 and September 2018 due to one campaign per month at the seven stations selected in the lake. These sampling stations were chosen according to their accessibility, water permanence and environmental characteristics.

Physico-chemical parameters such as temperature, $\mathrm{pH}$, dissolved oxygen and conductivity were measured in situ with a multi HANNA HI 9828PH / ORP / CE. Transparency and depth were also determined with Secchi's disc and a weighted string. Nitrate, nitrite, Kjeldahl nitrogen and total phosphorus were determined by the molecular absorption spectrophotometric method according to French Standards T90-012, T90-013, T90-023 and T90-110 respectively. The spectrophotometer (pharma UV -1700 / SHIMADZU evident) was used for these analyses. Total nitrogen was estimated from the addition of Kjeldahl nitrogen to nitrate and nitrite.

For phytoplankton sampling, one liter of water samples was collected at one meter from the surface at each station with an integrated sampler. The samples collected were stored in labelled bottles $(100 \mathrm{~mL})$ and fixed with $5 \%$ formaldehyde.

\subsection{Identification and Enumeration}

The samples were first observed between slide and coverglass under optical microscope made LEICA-type with objective 40x. The identification of phytoplankton down to the species level was carried out on morphological characteristics using a combination of works (Philipose, 1967; Compère, 1977; Couté \& Iltis, 1981; Komárek \& Fott, 1983; Uherkovich, 1995; Ouattara et al., 2000; Komárek \& Anagnostidis, 2005).

The enumeration of phytoplankton organisms was performed according to the Utermöhl (1958) method using a LEICA-type inverted microscope at $63 \mathrm{x}$ immersion magnification. After homogenization of the sample, a volume of $10 \mathrm{~mL}$ of the sample is taken and sedimented for 8 hours in a sedimentation tank. 35 fields were counted and in each field the number of cells (or counting unit) was determined. Moreover, a filament is considered as an individual and the number of cells is obtained by relating to the length of the filament the length of a cell, dimensions measured using an ocular micrometer. In the same way, the number of cells of the colonial algae is estimated by the measurement of the dimensions of the colony (form related to the nearest geometry). For simple shapes, the number of cells is determined at the time of counting. According to the AFNOR NF EN 15204 / T90-379 standard, a counting reliability of $5 \%$ is respected by counting (at least) 400 algal objects, as far as possible. Note that empty cells (without plastids) are not counted.

\subsection{Data and Statistical Analysis}

- Species richness, which is the number of taxa to which the taxa belong (Alliaume et al., 1990).

- The absolute density (Da) of the different algal groups encountered in a medium is determined using the following formula: $\mathrm{Da}=\mathrm{n} * \mathrm{~S} / \mathrm{s} * \mathrm{v}$ with $\mathrm{n}$ : the number of counted cells; $\mathrm{S}$ : the surface of the tank to be sedimented; s: the observed surface; v: sedimented volume.

- The relative density (Dr) is the density of each branch, group or entity on the total density of the middle individuals. It is expressed by $\mathrm{Dr}=\mathrm{d} / \mathrm{Da}$ with Dr: relative density; d: density of each branch; Da: absolute density. 
-Structure of the phytoplankton community was determined from the diversity index of Shannon and Weaver and the index of regularity of Pielou. The first index reflects how individuals are distributed among the various species that make up this stand (Daget, 1979) its expression is as follows: $H^{\prime}=-\sum_{i=0}^{R_{S}} q_{i} \times \log _{2}\left(q_{i}\right), q_{i}=$ proportion of the $\mathrm{i}^{\text {th }}$ species (i varying from 1 to $\left.R_{S}\right) ; R_{S}=$ total number of species. The second index reflects the quality of organization of a community in an environment (Amanieu \& Lasserre, 1982; Dajoz, 2000) and is expressed as follows: $E=\frac{H^{\prime}}{\left(\log _{2} \times R_{s}\right)} \times 100 ; E=$ equitability index; $H^{\prime}=$ Shannon-Wiener diversity index; $R_{S}=$ number of species

The statistical analysis was performed using PAST 3.24 software. From the principal component analysis (PCA), the realization of the factorial map, the correlation between the different parameters, and the classification of the months have been established (Hammer, 2011). The principle of the realization of the factorial map is based on the representation of the temporal distribution of the different parameters. The classification of the months rests on the grouping of these according to the parameters to study. Parametric test (t-test) was used to compare the abiotic and biotic variables studied at the 5\% significance level.

\section{Results and Discussion}

\subsection{Physicochemical Parameters}

Monthly and seasonal variations in the physicochemical characteristics of Dohou Lake are shown in Figure 2 and Table 1, respectively. Thus, averages of temperature values are between $25.44 \pm 0.56{ }^{\circ} \mathrm{C}$ (August) and $29.8 \pm 1.25{ }^{\circ} \mathrm{C}$ (October) (Figure 2a). Seasonal averages of this parameter are $26.55 \pm 1.55^{\circ} \mathrm{C}$ in rainy season and $27.62 \pm 1.55^{\circ} \mathrm{C}$ in dry season. Concerning electrical conductivity, the lowest mean value is observed in September $(39.71 \pm$ $\left.5.62 \mu \mathrm{S}^{-1}\right)$ and the highest average electrical conductivity value in June $\left(50.14 \pm 0.38 \mu \mathrm{S}^{-1}\right)$ (Figure 2b). During seasons, electrical conductivity changes between $43.27 \pm 3.16 \mu \mathrm{S}^{-1}$ in dry season and $43.38 \pm 4.19 \mu \mathrm{S}^{-1}$ in rainy season. For the average $\mathrm{pH}$ values, the extremes $4.82 \pm$ 0.39 and $6.82 \pm 0.23$ are respectively recorded in March and December (Figure 2c). In rainy and dry season, averages of $\mathrm{pH}$ are $5.75 \pm 0.44$ and $5.9 \pm 0.9$ respectively. For dissolved oxygen, means monthly values range from $2.64 \pm 1.06 \mathrm{mgL}^{-1}$ in April to $7.66 \pm 0.23 \mathrm{mgL}^{-1}$ in March (Figure 2d). Its average values are $4.93 \pm 1.97 \mathrm{mg}$. L ${ }^{-1}$ in dry season and $5.15 \pm 1.77 \mathrm{mg}^{-\mathrm{L}^{-1}}$ in rainy season. Transparency has the lowest average value $(0.39 \pm 0.14 \mathrm{~cm})$ in February and the highest average value in October $(0.82 \pm 0.24 \mathrm{~cm})$ (Figure 2e). In dry season, average value of transparency is $0.49 \pm 0.23 \mathrm{~m}$. Recorded average value of this parameter is $0.6 \pm 0.22$ in rainy season. As for the average of depth is low $(1.53 \pm 0.83 \mathrm{~m})$ in February and high $(2.45 \pm 0.74 \mathrm{~m})$ in November (Figure 2f). Depth varies on average from $2.19 \pm 0.98 \mathrm{~m}$ in dry season to $2.28 \pm 0.99 \mathrm{~m}$ in rainy season. As for the nitrate concentrations, the average values are noted between $1.56 \pm 0.315 \mathrm{mg} . \mathrm{L}^{-1}$ in January and $7.77 \pm 2.01 \mathrm{mg} . \mathrm{L}^{-1}$ in August (Figure $2 \mathrm{~g}$ ). Average nitrate value is low in dry season $\left(3.06 \pm 2.38 \mathrm{mg} . \mathrm{L}^{-1}\right)$ and high in rainy season $\left(6.4 \pm 6.21 \mathrm{mg}^{-1} \mathrm{~L}^{-1}\right)$. The monthly mean values of total nitrogen during the study period had the lowest average concentration $\left(2.74 \pm 0.53 \mathrm{mg}\right.$. $\left.\mathrm{L}^{-1}\right)$ in February and the high average 
concentration $\left(29 \pm 2.38 \mathrm{mg}\right.$. $\left.\mathrm{L}^{-1}\right)$ in November (Figure $2 \mathrm{~h}$ ). For this parameter, the averages are $11.4 \pm 10.34$ in dry season and $6.4 \pm 6.21$ during rainy season. The average total phosphorus was low $\left(1.91 \pm 0.45 \mathrm{mg} . \mathrm{L}^{-1}\right)$ in January and high $\left(5.19 \pm 2.01 \mathrm{mg}^{-1} \mathrm{~L}^{-1}\right)$ in September (Figure $2 \mathrm{i})$. For monthly mean nitrite concentrations, the values change between $0.014 \pm 0.002 \mathrm{~L}^{-1}$ in February and $0.0482 \pm 0.0141 \mathrm{mg} \mathrm{L}^{-1}$ in August (Figure 2j). Concerning seasonal changes, the averages of nitrite are $0.02 \pm 0.02 \mathrm{mg} \mathrm{L}^{-1}$ in season dry and $0.031 \pm 0.02$ in rainy.

A significant difference is observed between temperature, nitrate, total phosphorus and total nitrogen from the dry season to the rainy season ( $t$ test, $\mathrm{p}<0.05$ ).
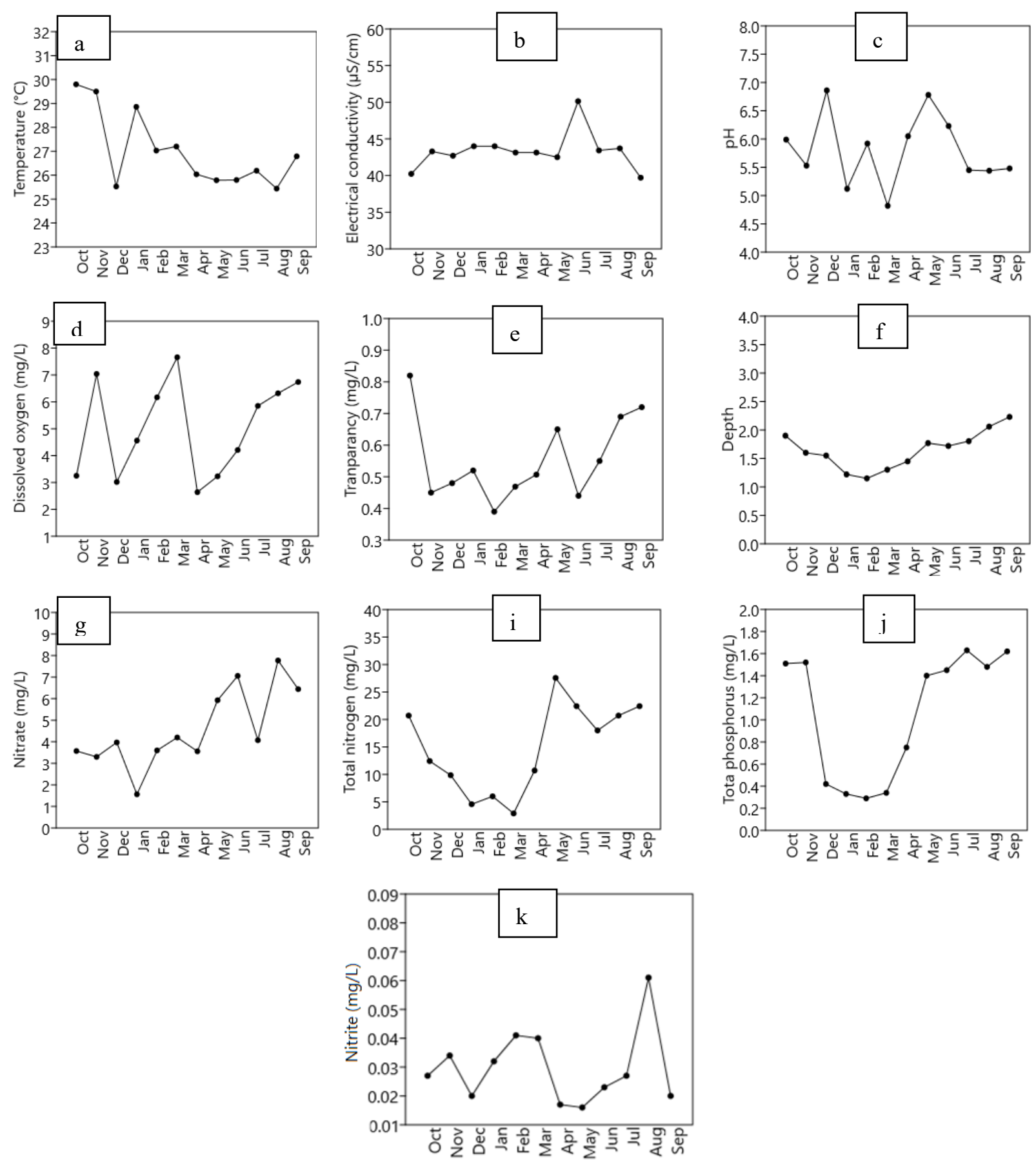
Figure 2.Monthly changes in average values of physicochemical parameters of Dohou Lake. a: Temperature, b: Electrical conductivity, $\mathrm{c}$ : $\mathrm{pH}$, d: dissolved oxygen, e: transparency, f: depth, g: nitrate, i: total nitrogen, $\mathrm{j}$ : total phosphorus, $\mathrm{k}$ : nitrite

Table 1. Seasonal variation of physical and chemical parameters in Dohou Lake

\begin{tabular}{llll}
\hline Parameters & DS & RS & $p$-value \\
\hline Temperature $\left({ }^{\circ} \mathrm{C}\right)$ & $27.62 \pm 1.55$ & $26.55 \pm 1.55$ & $p<0.05$ \\
Electrical Conductivity $(\mu \mathrm{S} / \mathrm{cm})$ & $43.27 \pm 3.16$ & $43.38 \pm 4.19$ & $p>0.05$ \\
$\mathrm{pH}$ & $5.9 \pm 0.9$ & $5.75 \pm 0.44$ & $p>0.05$ \\
Dissolved oxygen $(\mathrm{mg} / \mathrm{L})$ & $4.93 \pm 1.97$ & $5.15 \pm 1.77$ & $p>0.05$ \\
Total Nitrogen $(\mathrm{mg} / \mathrm{L})$ & $11.4 \pm 10.34$ & $21.67 \pm 5.75$ & $p<0.05$ \\
Nitrite $(\mathrm{mg} / \mathrm{L})$ & $0.02 \pm 0.02$ & $0.031 \pm 0.02$ & $p>0.05$ \\
Nitrate $(\mathrm{mg} / \mathrm{L})$ & $3.06 \pm 2.38$ & $6.4 \pm 6.21$ & $p<0.05$ \\
Total phosphorus $(\mathrm{mg} / \mathrm{L})$ & $0.58 \pm 0.5$ & $1.41 \pm 0.36$ & $p<0.05$ \\
Transparency $(\mathrm{m})$ & $0.49 \pm 0.23$ & $0.6 \pm 0.22$ & $p>0.05$ \\
Depth $(\mathrm{m})$ & $2.19 \pm 0.98$ & $2.28 \pm 0.99$ & $p>0.05$ \\
\hline
\end{tabular}

RS: Rain season and DS: Dry season;

The principal component analysis (PCA) carried out to determine the abiotic typology of Dohou Lake is presented in Figure 3. The results of this analysis show that the two first axes represent more than half of the total variance $(64.42 \%)$ of data (Figure 3a). Axis 1 expresses $38.22 \%$ of the total variance and axis 2 represents $26.2 \%$. The correlation circle shows that variables such as total nitrogen, total phosphorus, nitrate, transparency and depth are positively correlated with axis 1 . Axis 2 is positively correlated with dissolved oxygen, the temperature and the nitrite on the other hand the conductivity and the $\mathrm{pH}$ are negatively correlated with this axis. From the factorial map represented by Figure 3b, the axis 2 allows to separate the samples of the months of the rainy season (November, December, January, Februaly, March) from the months of the dry season (May, Jun, July, August, September, October). During the rainy months, the waters of Dohou Lake are influenced by high values of total phosphorus, total nitrogen, conductivity, nitrate, $\mathrm{pH}$, transparency and depth. However, in the dry months, the waters are characterized by high values of temperature and nitrite and dissolved oxygen and conductivity. 


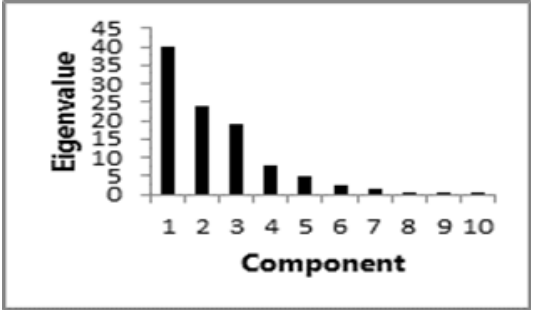

a

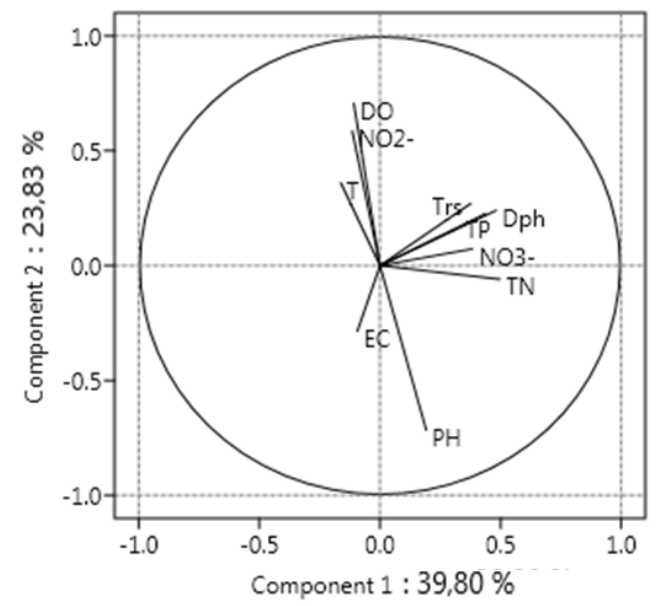

b

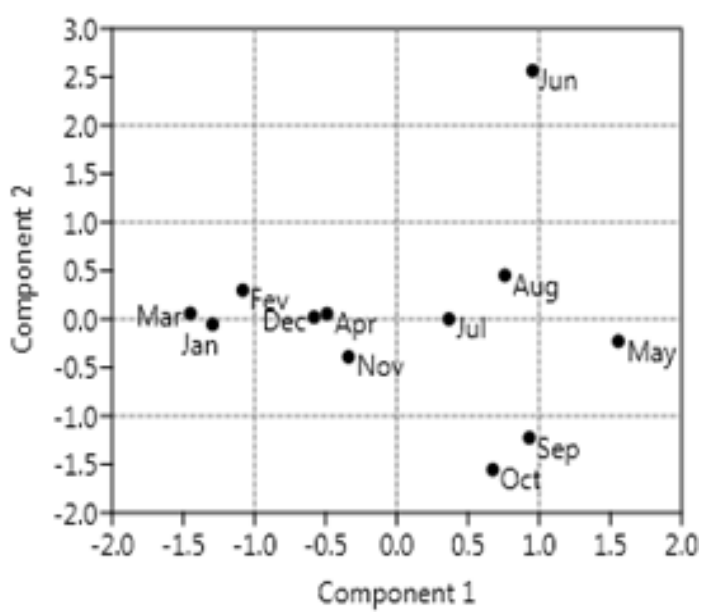

C

Figure 3. Monthly ordination of mean values of Dohou Lake physicochemical parameters from a Principal Component Analysis (PCA). a: Graph of eigenvalues; b: correlation circle; c: Factorial map. T: Temperature, EC: Electrical Conductivity, pH, O2: Dissolved Oxygen, Trs:

Transparency, Dph: Depth, TN: Total nitrogen, NO3-: Nitrate, NO2-: Nitrite, TP: Total phosphorus. Oct: October, Nov: November, Dec: December, Jan: January, Feb: February, Mar: March, Apr: April, Jul: July, Aug: August, Sep: September.

\subsection{Structure of the Phytoplankton Community}

The present study identified a total of 373 phytoplankton taxa during the study period. These taxa are divided into 111 genera, 51 families, 24 orders, 11 classes and 7 branches. The branches, in order of predominance, are Chlorophyta with 189 taxa or 50.67\%, Euglenophyta with 84 taxa or $22.52 \%$, Cyanobacteria represented by 46 taxa or $13.33 \%$, Bacillariophyta or diatoms with 42 taxa or $11.26 \%$, the other branches (Dinophyta, Chrysophyta, Pyrrophyta and Xanthophyta) represented by 12 taxa or $3.21 \%$ (Figure 4 ). 


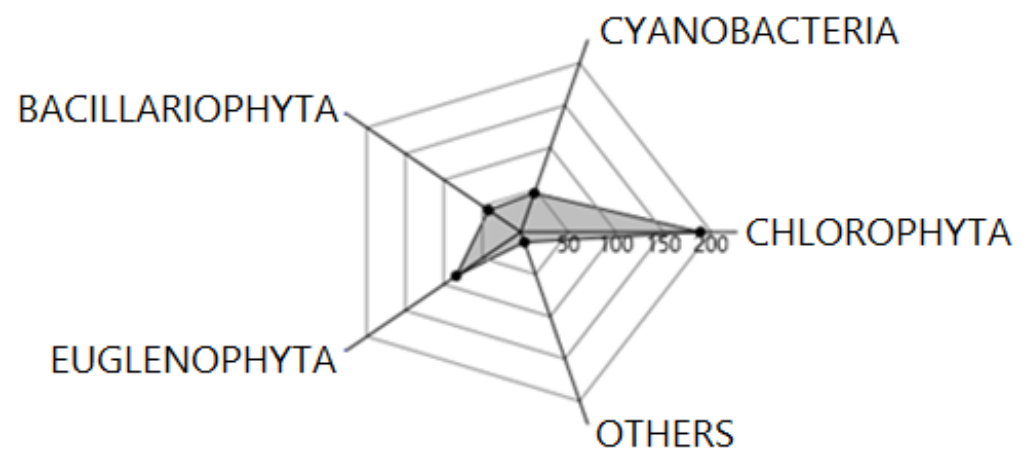

Figure 4. Phytoplankton composition of Dohou Lake

The monthly and seasonal changes in the phytoplankton density in Dohou Lake are shown in Figure 5 and Table 2 respectively. In this lake, mean of phytoplankton density values range from $14.3110^{6} \pm 6.2910^{6}$ cells/L (August) to $45.9710^{6} \pm 29.7910^{6}$ cells/L (January) (Figure 5a). A predominance of Cyanobacteria $(\geq 45 \%)$ is noted in the whole stand during the study period except November (18.19\%), December (11.16\%) and January (31.54\%) (Figure 5b). During these months, the proportions of the Bacillariophyta individuals occupying the second place are the most dominant with respectively $58.29 \%$ and $56.09 \%$ and $37.14 \%$. The density proportions of the two branches are followed by those of the Euglenophyta which vary from $2.74 \%$ to $12.9 \%$. The others (Chlorophyta, Dinophyta, Chrysophyta, Xanthophyta) are in low proportion with 0.78 to $9.1 \%$. Seasonally, the average of phytoplankton density is higher in dry season $\left(34.2110^{6} \pm 23.810^{6} \mathrm{Cells} / \mathrm{L}\right)$ than in rainy season $\left(24.7110^{6} \pm 16.410^{6} \mathrm{Cells} / \mathrm{L}\right)$ (Table 2). Concerning seasonal proportions, cyanobacteria (81\%) are most dominant of the phytoplankton community in rainy season while Bacillariophyta $(27 \%)$ are dominant in dry season (Table 2). A significant difference in phytoplankton density is observed between seasons ( $\mathrm{t}$ test, $\mathrm{p}<0.05$ ). 

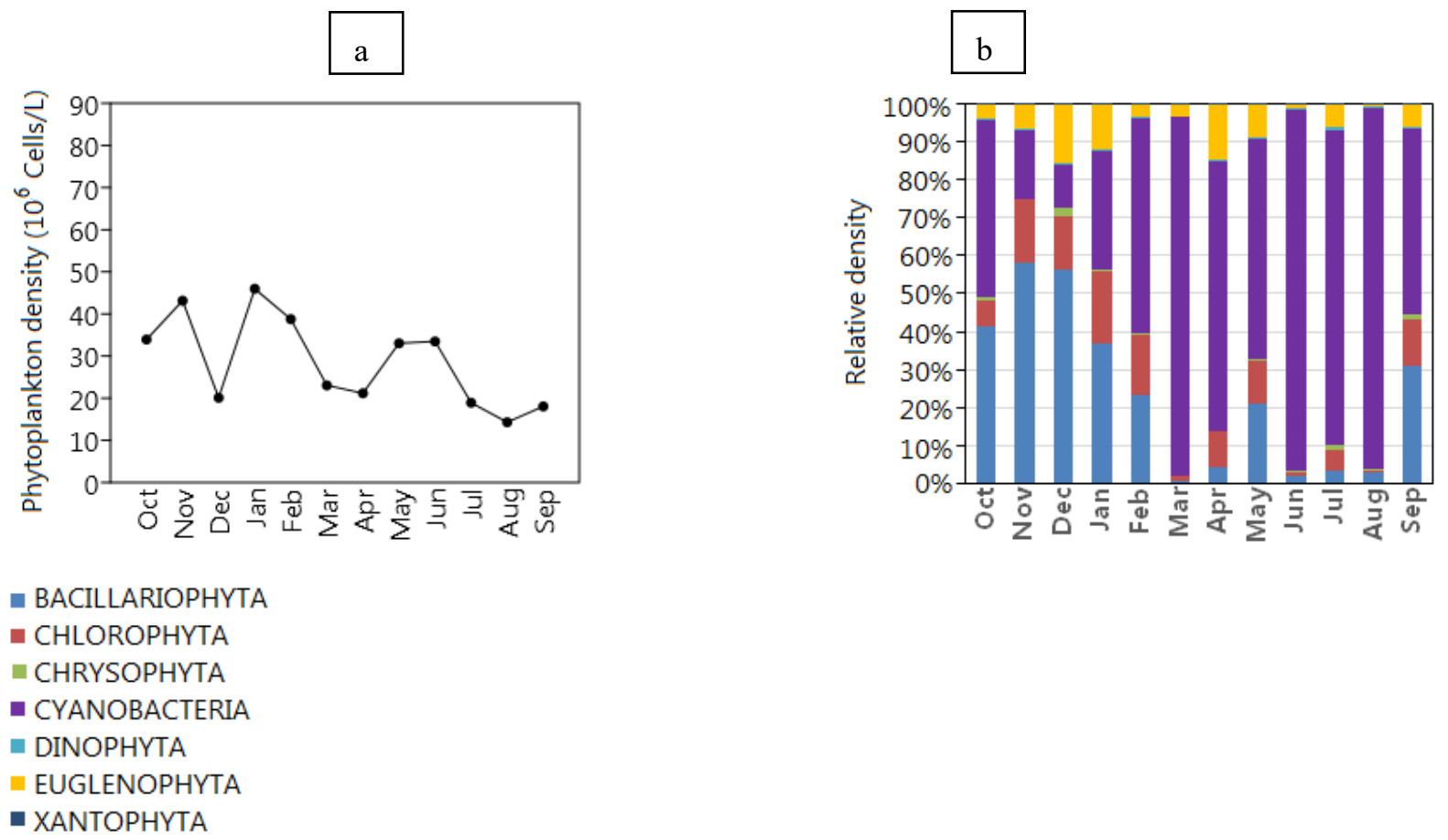

Figure 5. Monthly changes in phytoplankton density of Dohou Lake. a: absolute density; b: relative density

Table 2. Seasonal change in the phytoplankton density and phytoplankton branches of Dohou Lake

\begin{tabular}{|c|c|c|c|}
\hline \multicolumn{4}{|c|}{ Seasons } \\
\hline Phytoplankton Density & Dry season & Rainy season & P-value \\
\hline \%Bacillariophyta & 27 & 11 & \\
\hline$\%$ Chlorophyta & 15 & 4 & \\
\hline \%Chrysophyta & 0 & 0 & \\
\hline$\%$ Cyanobacteria & 52 & 81 & \\
\hline \%Dinophyta & 0 & 0 & \\
\hline \%Euglenophyta & 6 & 4 & \\
\hline \%Xanthophyta & 0 & 0 & \\
\hline Total Density $\left(10^{6}\right.$ Cells/L) & $34.21 \pm 23.8$ & $24.71 \pm 16.4$ & $P<0.05$ \\
\hline
\end{tabular}

The monthly and seasonal changes in the means values of diversity indexes of the Dohou Lake are shown in Figure 6 and Table 2 respectively. The highest averages values of the Shannon index (2.12 bits/cells) and Equitability (0.6) are observed in January. The smallest average index is recorded in June with respectively 1.1 bits / cells for the Shannon index and 0.32 for Equitability index. The average values of Shannon index $(1.91 \pm 0.66 \mathrm{bits} / \mathrm{cells})$ and Equitability $(0.54 \pm 0.15)$ are higher during dry season than in rainy season (Table 2$)$. A 
significant difference in diversity index is observed between seasons ( $t$ test, $p<0.05)$.

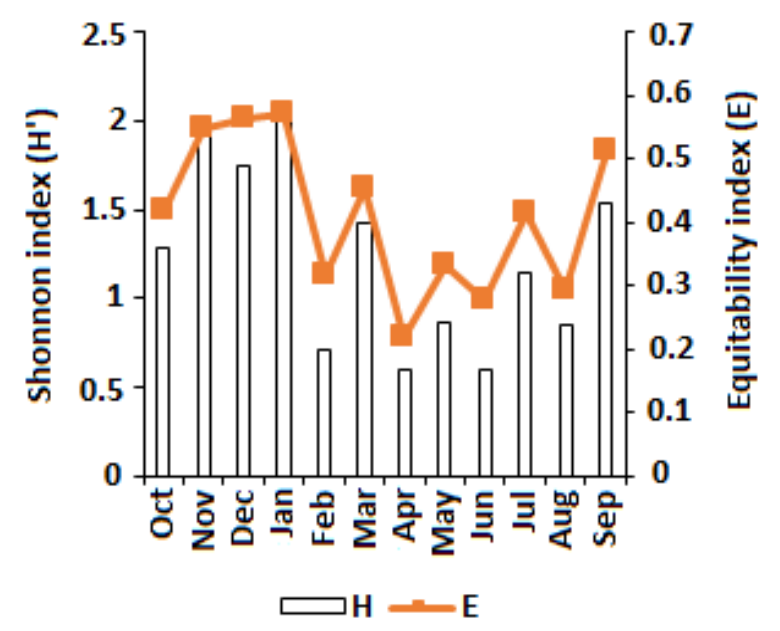

Figure 6. Monthly variations of the Shannon and equitability indexes of phytoplankton community in Dohou Lake

Table 2. Seasonal changes of the diversity indexes of phytoplankton community in Dohou Lake

\begin{tabular}{llll}
\hline Index & Rainy Season & Dry Season & $p$-value \\
\hline Shannon (bits/cells) & $1,49 \pm 0,74$ & $1,91 \pm 0,66$ & $p<0.05$ \\
Equitability & $0,44 \pm 0,18$ & $0,54 \pm 0,15$ & $p<0.05$ \\
\hline
\end{tabular}

\subsection{Discussion}

\subsubsection{Physicochemical Parameters}

Changes in physicochemical parameters of Dohou Lake have highlighted several interactions between ecological factors. The average monthly temperature above $25{ }^{\circ} \mathrm{C}$ shows that the lake is relatively hot. However, water temperatures generally remain influenced by climatic conditions due to insolation and precipitation, which could control (accelerate or slow down) the rates of chemical and biochemical reactions (Issola et al., 2008). These recorded temperature values correspond to those obtained by Kouassi-blé (2013) in the Adzopé reservoir and those often observed in aquatic ecosystems with a subequatorial climate (Agadjihouèdé et al., 2016). Over the months, water of Dohou Lake is relatively acidic with average $\mathrm{pH}$ values of 4.82 and 6.86. This acidity is related to the production of $\mathrm{CO}_{2}$ under the action of biological activities and rainy inputs (Lasm et al., 2008). Indeed, the hydration of $\mathrm{CO}_{2}$ produces the carbonic acid whose ionization releases $\mathrm{H}^{+}$ions that contribute to the acidity of the water (Konan et al., 2017). According to some authors, the acidity of inland waters is related to the supply of humic acids from soil leaching, wastewater discharge and macrophyte decomposition under the action of bacteria (Korfali \& Davies, 2003). These results are consistent with those of Kouamé et al. (2019) obtained on the same lake. In general, natural waters have $\mathrm{pH}$ values between 4.5 and 9 (Kortatsi, 2007). The average water conductivities 
(less than $55 \mu \mathrm{S} / \mathrm{cm}$ ) of the lake suggest an average dissolution of minerals in the watershed. The mean dissolved oxygen level of $4.93 \mathrm{mg} / \mathrm{L}$ during the dry season months and $5.15 \mathrm{mg} / \mathrm{L}$ during the rainy month is above the critical limit value $(4 \mathrm{mg} / \mathrm{L})$ set according to Sewage Discharge Ordinance, below which the life of aerobic microorganisms is threatened (Cornaz, 2004). This variation in the oxygenation of the lake water may be due either to exchanges at the air-water interface, to the diffusion within the body of water or to the photosynthetic activity of the algae which, in the presence of sunlight, captures the atmospheric $\mathrm{CO}_{2}$ to transform it into $\mathrm{O}_{2}$ to aerate the medium or to a consumption of oxygen dissolved by aerobic bacteria for the degradation of organic matter (Amon, 2017). The values of this parameter are similar to those found by Kouamé et al. (2019) on the same lake. The average transparency of the lake water does not exceed 1 meter during the study period. On the other hand, the average values of this parameter are lower in the rainy season $(0.49 \mathrm{~m})$ than in the dry season $(0.6 \mathrm{~m})$. The high average transparency values during the dry season can be explained by stability due to the lack of water flow, which leads to a decrease in the density of suspended particles. In addition, during the rainy season, the arrival of runoff water loaded with solids and suspended matter would contribute to disturbing lake water, resulting in low average transparency values. Our results are similar to those of Kouamé et al. (2019) on Dohou lake. Nitrogen compounds (total nitrogen, nitrate, nitrite) are essential constituents of organic matter and enter into the composition of cellular proteins. These compounds in mineral form are used by algae for their development. Their high concentration in Dohou Lake especially during the rainy season could be related to the leaching of cultivated land, maintained by fertilizers (chemical and organic) and phytosanitary products. The high monthly concentrations of nitrates coincide with the rainy season (Jun, August, September) whereas they gradually decrease at the end of the dry season (November, December, January, February, March) following the limitation of inputs and probably to intensification of the denitrification process. Nitrite comes from the oxidation of nitrogenous organic matter. They are maintained only in low oxygenated environments, because, unstable they tend to oxidize nitrates (Dussart, 1992). Nitrites are a form of transition during ammonium oxidation or nitrate reduction. The monthly averages of nitrite concentrations in the lake are in the same direction as those of nitrate and total nitrogen. The monthly mean total phosphorus during the study period remains high during the months of the rainy season (April, May, Jun, July, August, September) and low during the dry season months (December, January, February, March). These high monthly average values of total phosphorus in the rainy season could be due to human activities. Indeed, urban effluents and waste from vegetable crops, chicken farm, stray animals and quarry nearby are discharged directly into the lake. Finally, all the conditions favoring the eutrophication of the environment are characterized by the high nutrients, dissolved oxygen during the rainy season and the high temperature, $\mathrm{pH}$ in the dry season. It is precisely at this time that the nuisances of eutrophication are likely to manifest themselves.

\subsubsection{Structure of the Phytoplankton Community}

During the study period, 373 were recorded in Lake Dohou. The study lake can be considered taxon-rich. This richness may be related to the high number of taxa belonging to the Chlorophyta branch. This number is approximately equal to the number of taxa reported by Compère (1991) who determined 397 taxa at Lac Guiers. The number of taxa is also higher 
than those found in the Azopé water reservoir in Côte d'Ivoire (212 species, Adon, 2012). In this taxonomic composition, the predominance of Chlorophyceae is noted. This result is similar to that of Bouvy (2006) after the construction of the Diama Antisel dam on the Senegal River, where a high proportion of Chlorophyceae is observed. According to Iltis (1982), in fresh water, Chlorophyta has the highest species richness.

Overall, Dohou Lake phytoplankton is abundant and heterogeneous over time. A significant difference appears in seasonal density fluctuations. Samples collected generally during the dry months (November, January and February) are higher in phytoplankton densities than the months of the rainy season. The high densities during these months coincide with the high temperature that would stimulate the biological process such as multiplication of phytoplankton cells in relation to nutrient consumption. This abundance is due to a very large number of filaments or cells united in colonies belonging to some species. These species are Aphanocapsa conferta, Microcystis aeruginosa, Planktolyngbya limnetica, Chroococcus minutus, Asterionella formosa, Aulacoseira ambigua, Pinnularia acrosphaeria, Trachelomonas volvocina, Trachelomonas cylindrica and Dictyosphaerium pulchellum. The density of phytoplankton in the samples made it possible to note a contribution of various taxonomic groups.

The dominance of Cyanobacteria clearly appeared in our results. During each month of the study period, Cyanobacteria contribute significantly to increase the absolute density of Dohou Lake except during the dry season months (November, December, January) when Bacillariophyta dominates the phytoplankton community. The dominance of Cyanobacteria during months and / or seasons is due to the fact that this category of algae adapts to a multitude of environmental conditions and is able to proliferate under extreme conditions (Lavoie et al., 2007). Indeed, during the months of the rainy season (April, May, Jun, July, August, September) the predominance of Cyanobacteria could be justified by several environmental factors including the high availability of nutrients (nitrogen and phosphorus) in mineral form, coming from watershed leaching for which Cyanobacteria have more affinity than other algae (Blais, 2002). On the other hand, the period of excessive multiplication (November, December, January) of Bacillariophyta (Diatoms) coincides with a low nutrient content. This result is supported by the assertion of Berdalet et al. (1996) that diatom multiplication is mainly related to the decline of nitrogen nutrients. This same seasonal period with the months of February, March and April also causes the proliferation of Cyanobacteria. The predominance of this taxonomic group may be related to adaptation strategies developed by this group to avoid being targeted by phytophagous organisms (zooplankton and phytophagous fish). Indeed, according to Haney (1987), Cyanobacteria can secrete toxins of various types that give them a "bad taste" to protect themselves against grazers, but also to eliminate competitors competing for the same resources (Pearl and Millie, 1996). They also live in large colonies to pass through the filtering mechanisms of grazers (Lampert, 1987). This can be seen with the dominant species such as Planktolyngbya limnectica, Aphanocapsa conferta, Chroococcus minutus, and Microcystis aeruginosa. The production of these toxic compounds would contribute to increasing the competitive advantage of Cyanobacteria on other branches of algae in achieving the dominance of an aquatic environment (Affsa / Afsset, 2006). 
The temporal variations of the average values of the Shannon indices generally do not exceed 2 bits/cells. These values show a low diversity characterized by a young population with a high breeding power including one species or a small number of predominant species (Kemka et al., 2004). Some authors, Bozniak and Kennedy (1968), Margalef (1964) and Mason (1991), mention that eutrophic lakes generally have a low specific diversity compared to oligotrophic lakes and present macrophyte invasions. With regard to the specific diversity values obtained in Dohou Lakes ( 2 bits/cell on average), and the presence of blooms during the study year could indicate eutrophic lake conditions. Within the same range of variation, Elber and Schanz (1989) found $\mathrm{H}^{\prime}$ diversity values ranging from 0.13 to 2.32 in Lake Kaminsee I and from 1.26 to 2.83 in Lake Kaminsee II in Germany. As for the fairness index, time values range from 0.22 in April to 0.57 in January. These values reflect the heterogeneity of the phytoplankton community studied, which would be regularly unbalanced.

\section{Conclusion}

This study identified 373 phytoplankton taxa in Dohou Lake. These taxa are divided into 7 phytoplankton branches and the most diverse in terms of species richness are Chlorophyta and Euglenophyta. The structure of the phytoplankton community shows variability over time. In terms of density, cyanobacteria and Bacillariophyta are the most dominant in the Dohou Lake phytoplankton community. This structure based on diversity index values reflects a disturbed and unstable environment. An assessment of the trophic status and ecological quality of this lake would therefore be necessary in perspective.

\section{References}

Adjahouinou, D. C., Liady, N. D., \& Fiogbe, E. D. (2012). Diversité phytoplanctonique et niveau de pollution des eaux du collecteur de Dantokpa (Cotonou-Bénin). International Journal of Biological and Chemical Sciences, 6(5), 1938-1949, https://doi.org/10.4314/ijbcs.v6i5.4

Adon, M. P., Ouattara, A., \& Gourene G. (2012). Phytoplankton composition of a shallow african tropical reservoir (Adzopé, Côte d'Ivoire), Journal of Microbiology, Biotechnology and Food Sciences, 1(5), 1189-1204.

Afssa/Afsset. (2006). Évaluation des risques liés à la présence de cyanobactéries et de leurs toxines dans les eaux destinées à l'alimentation, à la baignade et autres activités récréatives. Rapport commun sur les risques sanitaires liés à la présence de cyanobactéries dans l'eau.

Aliaume, C., Lasserre, G., \& Louis, M. (1990). Organisation spatiale des peuplements ichtyologiques des herbiers à Thalassia du Grand Cul-de-sac marin en Guadeloupe. Revue d'hydrobiologie Tropicale, 23(3), 231-250.

Amanieu, M., \& Lasserre G. (1982). Organisation et évolution des peuplements lagunaires. Oceanologica Acta, 4, 201-213.

Amon, N. L., Konan, K. L., Coulibaly, S., Yapo, Y., Oyetola, S., \& Dosso, M. (2017). Characterization and Typology of Aghien Lagoon Waters (South East of Côte d'Ivoire): Potential Resources for Drinking Water Production. Journal of Applied Chemistry, 10, 2278-5736. https://doi.org/10.9790/5736-1001020107

Anneville, O., Kaiblinger, C., Tadonléké, R. D., Druart, J. C., \& Dokulil, M. T., (2008). Contribution of Long-Term Monitoring to the European Water Framework Directive 
Implementation.

Balvay, G. (1985). Structure et fonctionnement du réseau trophique dans les retenues artificielles. Gestion piscicole des lacs et retenues artificiels. INRA, Paris: 39-66.

Baxter, R. M., \& Glaude, P. (1980). Les effets des barrages et des retenues d'eau sur l'environnement au canada: expériences et perspectives. Canada bulletin Fish aquatic sciences, $36 \mathrm{p}$.

Berdalet, E., Marrasé, C., Estrada. M., Arin, L., \& Mac Lean, L. M. (1996). Microbial community responses to nitrogen and phosphorus deficient nutrient inputs microplankton dynamics and biochemical characterization. Journal of plankton Research, 18(9), 1627-1641. https://doi.org/10.1093/plankt/18.9.1627

Blais, S. (2002). La problématique des cyanobactéries (algues bleu-vert) à la baie Missisquoi en 2001. Agrosol, 13(2), 103-110.

Bouvy, M., Ba, N., Ka, S., Sane, S., \& Pagano, M. (2006). Phytoplankton community and species assemblage succession in a shallow tropical lake (lake Guiers, Senegal). Aquatic Microbiologie Ecology, 45(2), 147-161. https://doi.org/10.3354/ame045147

Bozniak, E. G., \& Kennedy, L. L. (1968) Periodicity and ecology of the phytoplankton in an oligotrophic and eutrophic lake. Canadian Journal of Botany, 46(10), 1259-1271. https://doi.org/10.1139/b68-168

Brou, Y. T. (2005). Climat, mutations socio- économiques et paysages en Côte d'Ivoire. Mémoire de synthèse des activités scientifiques présenté en vue de l'obtention de l'Habilitation à Diriger des Recherches, Université des sciences et technologies de Lille, France, p.226.

Carmichael, W. W., Jones, C. L. A., Mahmood, N. A., Theiss, W. C., \& Krogh P. (1985). Algal toxins and water-based diseases. Critical Reviews in Environmental Science and Technology, 15(3), 275-313. https://doi.org/10.1080/10643388509381734

Collins, S., Rost, B., \& Rynearson, A. T. (2014). Evolutionary potential of Marine phytoplankton under ocean acidification Evolutionary applications, John Wiley \& Son Ltd, 7(1), 140-55. http://doi.org/10.1111/eva.12120

Compère, P. (1991). Contribution à l'étude des algues de Sénégal. 1. Algues du lac de Guiers et du Bas-Sénégal. Bulletin du Jardin Botanique National Belgique, 61(3/4), 171-267. https://doi.org/10.2307/3668149

Cornaz, S. (2004). Evaluation du statut trophique d'un canal de drainage sous l'impact des pollutions d'origines diffuses et ponctuelles, le cas du grand canal de plaine de Rhône. Geography Institut of University of Lausanne, $180 \mathrm{p}$.

Couté, A., \& Iltis, A. (1981). Ultrastructure de la logette de Trachelomonas (Algae, Euglenophyta) récoltés en Côte d'Ivoire. Revue Hydrobiologie Tropicale, 14(2), 115 - 133.

Couté, A., \& Bernard, C. (2001). Les cyanobactéries toxiques. In J. M Frémy, \& P. Lassus (Eds) Toxines d'algues dans l'alimentation, (pp. 21-37), Paris: Ifremer

Daget, J. (1979). Les modèles mathématiques en écologie. Éditions Masson, Paris, 172 p.

Dajoz, R. (2000). Précis d'écologie. (7ième ed). Paris : Dunod, 615 p.

Dussart, B. (1992). Limnologie. L'étude des eaux continentales. 2ème édition. Collection « 
faunes et flores actuelles », $680 \mathrm{p}$.

Eblin, S. G., Sombo, A. P., Soro, G., Aka, N., Kambiré O., \& Soro N. (2014). Hydrochimie des eaux de surface de la région d'Adiaké. Journal of Applied Biosciences, 75, 6259-6271. https://doi.org/10.4314/jab.v75i1.10

Elber, F., \& Schanz, F. (1989). The cause of change in the diversity and stability of phytoplankton communities in small lake. Freshwater Biology, 21, 237-251. https://doi.org/10.1111/j.1365-2427.1989.tb01362.x

Furnas, M. J. (1991). Net in situ growth rates of phytoplankton in an oligotrophic, tropical shelf ecosystem. Limnology and Oceanography, 36(1), 13-29, https://doi.org/10.4319/1o.1991.36.1.0013

Haney, J. F. (1987). Field studies on zooplankton-cyanobacteria interactions. New Zealand Journal of Marine and Freshwater Research, 21(3), 467-475. https://doi.org/10.1080/00288330.1987.9516242

Hammer, O., Harper, D. A.T., \& Ryan, P. D. (2001). Paleontological Statistics Software Package for Education and Data Analysis. Paleontologica Electronica, 4(1), 1-9.

Iltis, A. (1982). Peuplements algaux des rivières de Côte d'Ivoire. I. Stations de prélèvement, méthodologie, remarques sur la composition quantitative et les biovolumes. Revue d'Hydrobiologie tropicale, 15(3), 231 - 239.

Issola, Y., Kouassi, A. M., Dongui, B. K., \& Biemi, J. (2008). Caractérisation physicochimique d'une lagune côtière tropicale: lagune de Fresco (Côte d'Ivoire), Afrique Sciences, 4(3), 368-393. https://doi.org/10.4314/afsci.v4i361696

John, D. M. (1986). The inland waters of tropical West Africa. An introduction and botanical review. Arch. Hydrobiol, 23, 1-244. https://doi.org/10.1007/BF00006211

John, D. M., Obeng-Asamoa, E. K., \& Appler, H. N. (1981). Periphyton in the Volta Lake. II. Seasonal changes on wooden blocks with depth. Hydrobiologia, 76(3), 207-215.

Kemka, N., Njiné, T., Zébazé-Togouet, S. H., Niyitegeka, D., Nola, M., Monkiedje, A., Demanou, J., \& Foto-Menbohan, S. (2004). Phytoplankton of the Yaounde municipal lake (Cameroon): ecological succession and population structure. Revue des Sciences de l'Eau, 17(3), 301-316. https://doi.org/10.7202/705535ar

Komárek, J., \& Anagnostidis, K. (2005). Cyanoprokaryota -2. Teil/ 2nd Part : Oscillatoriales. In B. Büdel., L. Krienitz., G. Gärtner, \& M. Schagerl (Eds.), Süßwasserflora von Mitteleuropa (1-759 p 19/2, Elsevier/Spektrum, Heidelberg.

Komárek J. \& Fott B., (1983). Chlorophyceae (Grünalgen) Ordnung : Chroococcales. In G. Huber-Pestalozzi (Ed.), Das Phytoplankton des Sübwassers, (pp. 1-1044).

Konan, K. S., Kouakou, K. B., Ohou, M. J., Konan, K. F., \& Dongui, B. K. (2017). Variation saisonnière des paramètres abiotiques de la lagune Aghien (côte d'ivoire). Journal of Applied Biosciences, 120, 12042-12052.

Kortatsi, B. K., Tay, C. K., Anornu, G., Hayford, E., \& Dartey, G. A. (2008). Hydrogeochemical evaluation of groundwater in the lower Off in basin, Ghana. Environmental Geology, 53(8), 1651-1662. https://doi.org/10.1007/s00254-007-0772-0

Kortatsi, B. K. (2007). Hydrochemical framework of groundwater in the Ankobra Basin, 
Ghana. Aquaic. Geochemie, 13, 41-74. https://doi.org/10.1007/s10498-006-9006-4

Kouamé, K. B., Konan, K. S., Attoungbre, K. S., Konan, K. F., Boussou, K. C., \& Kouamé, K. M. (2019). Qualitative assessment and typology of the water resource used for the production of drinking water in Duékoué, western Côte d'Ivoire, Journal of Geoscience and Environment Protection, 7, 212-231. https://doi.org/10.4236/gep.2019.75017

Kouassi, M. A., Ahoussi, K. E., Koffi, Y. B., AKE, Y. A., \& Biemi, J. (2012). Caractérisation hydrogéochimique des eaux des aquifères fissurés de la zone Guiglo-Duekoué (Ouest de la Côte d'Ivoire). International Journal of Biological Chemical Sciences, 6(1), 504-518. https://doi.org/10.4314/ijbcs.v6i1.45

Kouassi-Blé, A. T. (2013). Taxinomie, composition floristique et dynamique spatio-saisonnière des algues périphytiques de la retenue d'eau d'Adzopé (Côte d'Ivoire). University of Félix Houphouët-Boigny, PhD Thesis, Abidjan.

Lampert, W. (1987). Laboratory studies on zooplankton-cyanobacteria interactions. New Zealand Journal of Marine and Freshwater Research, 21, 483-490, https://doi.org/10.1080/00288330.1987.9516244

Lasm, T., Yao, K. T., Oga, M. S., Kouame, K. F., Jourda, P., Kouadio, K. E., \& Baka, D. (2008). Analysis of the physico-chemical characteristics of groundwater in proterozoic land region of the Tiassale area (Southern Côte d'Ivoire). European Journal of Scientific Research, 20(3), 526-543.

Lavoie, I., Laurion, I., Warren, A., \& Vincent, W. (2007). Les fleurs d'eau de Cyanobactéries. Revue de littérature. Institut national de la recherche scientifique, rapport 916 (xiii), 124.

Mama, D., Azokpota, E., \& Youssoa, A. (2019). Qualité physico-chimique des eaux de surface utilisées comme eaux de boisson dans les communes d'Agbangnizoun et de Zakpota au Benin. VII ième Colloque des sciences, culture et technologies sur le thème : la valorisation des résultats de recherche et de l'innovation technologique un facteur de développement des nations, du 16 au 21 septembre 2019, Cotonou, Benin, pp 166.

Margalef, R. (1964). Correspondence between the classic type of lake and the structural and dynamic properties of their populations. Verhandlungen der International fûr Limonogie, 15, 169-175, https://doi.org/10.1080/03680770.1962.11895518

Mason, C. F. (1991). Biology of freshwater pollution. Second edition, Longman Scientific \& Technical, New York, 350 p.

Morin, S. (2006). Bio-indication des effets des polluants métalliques sur la communauté des diatomées benthiques, approches in situ et expérimentales. $\mathrm{PhD}$ Thesis, University of Bordeaux, (Bordeau, France), 320 p.

Naselli-Flores, L. (2000). Phytoplankton assemblages in twenty-one Sicilian reservoirs: relationships between species composition and environmental factors. Hydrobiologia, 424, 1 - 11. https://doi.org/10.1023/A:1003907124528

Nunes, S., Latasa, M., Gasol, M. J., \& Estrada, M. (2018). Seasonal and interannual variability of phytoplankton community structure in a Mediterranean coastal site. Marine Ecology Progress Series, 592, 57-75, https://doi.org/10.3354/meps 12493

Ouattara, A. (2000). Premières données systématiques et écologiques du phytoplancton du lac 


\section{Macrothink}

d'Ayamé (Côte d'Ivoire). PhD Thesis, University of Leuven, Belgique, 226 p.

Pearl, H. W., \& Millie, D. F. (1996). Physiological ecology of toxic aquatic Cyanobacteria. Phycologia, 35, 160-167, https://doi.org/10.2216/i0031-8884-35-65-160.1

Philipose, M. T. (1967). Chlorococcales. ICAR Indian Council of Agricultural Reseach, New Delhi, 174.

Rondel, C., Arfi, R., Corbin, D., Le Bihan, F., Ndour, E. H., \& Lazzaro, X. (2008). A cyanobacterial bloom prevents fish trophic cascades. Freshwater Biology, 53, 637-651, https://doi.org/10.1111/j.1365-2427.2007.01894.x

Uherkovich, G. (1995). A Scenedesmus zöldalganemzetség (Chlorococcales, Chlorophyceae) különös tekintettel magyarországi elöfordulású taxonjaira. Magyar Algológiai Társaság, Budapest, 266.

Utermöhl, H. (1958). Zur Vervollkommnung der quantitativen Phytoplankton-Methodik. Int. Ver. theor. angew. Limnol., 9, 1-39. https://doi.org/10.1080/05384680.1958.11904091

\section{Copyright}

Copyright for this article is retained by the author(s), with first publication rights granted to the journal.

This is an open-access article distributed under the terms and conditions of the Creative Commons Attribution license (http://creativecommons.org/licenses/by/4.0/). 